\title{
Plasmodiophora brassicae (Clubroot): A Plant Pathogen that Alters Host Growth and Productivity
}

\author{
Geoffrey Richard Dixon, Guest Editor
}

Published online: 23 April 2009

(C) Springer Science+Business Media, LLC 2009

\section{Dedication:}

This special edition is dedicated to the memory of Hille Toxopeus, Dutch plant breeder and pathologist who conceived the European Clubroot Differential Series (ECD) which brought order from chaos, and Takashi ("Taka") Naiki, Japanese plant pathologist whose patient and intensive studies of the biology of Plasmodiophora brassicae dispelled many mysteries. My privilege was working with both great men who shared an infectious love of life and fascination with clubroot.

G. R. Dixon $(\bowtie)$

Centre for Horticulture \& Landscape, School of Biological Sciences,

The University of Reading, Whiteknights, P.O. Box 221, Reading,

Berkshire RG6 6AS, UK

e-mail: geoffrdixon@btinternet.com 